one billion hectares of land, roughly twice as much as all arable lands (Table 1). Since ruminant livestock constitute the principal means of utilizing grazing lands for human support, it is noteworthy that the total ruminant livestock populations in the 60 less-developed nations amount to about 4 billion "sheep units." (One cow or buffalo = five sheep; and one goat = one sheep. Sheep are the most universal type of ruminant grazed on tropical grasslands, although cattle predominate in many regions.)

Unfortunately, the current productivity of these herds and flocks is rarely more than one-fourth as high as that realized from livestock on U.S. rangelands. This is highly significant since these livestock constitute a major source of animal proteins for human diets in these countries, and present levels of animal protein intake are very low. In general, proteins of plant origin are deficient in one or more of four amino acids that are essential for human nutrition (lysine, methionine, threonine, tryptophan); and animal proteins are required to balance amino acid needs. Peoples of less-developed countries are subsisting on diets that are not only low in total protein, but these diets contain less than half the animal proteins consumed per capita in western Europe and North America. One major hope for more nearly meeting animal protein needs for peoples of the tropics and subtropics is by increasing supplies of meat from ruminants grown on permanent grasslands.

Aside from the urgent need to improve protein components of diets within each country, there is a great and growing demand for meats in countries that are seeking imports, including Japan, the oil rich countries of the Middle East and North Africa, Western Europe, and North America. The less developed countries need to earn foreign exchange, and meat exports are a prime commodity for such trade. To fully exploit this opportunity, there must be greatly improved efficiency in meat production and adequate sanitary precautions to avoid dissemination of animal diseases.

\section{Ecological Zones}

The major resources for expanded meat production are the permanent grasslands of the tropics and subtropics. These occur in four major ecological zones, and management of grasslands and livestock should be adjusted to the conditions in each zone, as well as to the peoples and livestock now present. Some dominant features of each zone should be noted.

\section{The Humid Tropics}

The humid tropics have an average rainfall of 40 to 80 inches, with relatively short dry seasons not exceeding 3 months. These lands have been cleared of forest, and crops are grown on arable soils. Native grass occupies lands that are too steep and erosive, or have shallow soils, or are stony, poorly drained, or otherwise nonarable. These lands are grazed by communal herds and flocks, in which individual animals are personally owned by villagers but have unlimited access to the grazing lands. Each farmer uses his animals to consume his crop wastes (stalks, straw, vines, etc.), but there is little or no production of seeded forages to support livestock. In general, these communal grazing lands are overstocked, and no regulated use or improvement is practiced.

The humid tropical regions offer very great opportunities for improved feed production, that should include the introduction of improved grasses and legumes into the communal grazing lands and more appropriate management of
Table 1. Native grassland ${ }^{1}$ and ruminant livestock populations ${ }^{2}$ of the tropics and subtropics.

\begin{tabular}{|c|c|c|c|c|}
\hline Item & $\begin{array}{c}\text { South } \\
\text { America }^{3}\end{array}$ & $\mathrm{Asia}^{3}$ & Africa $^{3}$ & Total \\
\hline \multicolumn{5}{|l|}{ Permanent native grasslands } \\
\hline Grasslands (million ha) & 189 & 167 & 612 & 968 \\
\hline Arable (million ha) & 47 & 301 & 157 & 505 \\
\hline \multicolumn{5}{|l|}{ Livestock (million animals) } \\
\hline Cattle & 190 & 279 & 143 & 612 \\
\hline Sheep and goats & 154 & 340 & 256 & 750 \\
\hline Buffalo and camels & - & 91 & 10 & 101 \\
\hline Total sheep unit equivalents ${ }^{4}$ & 1,104 & 2,190 & 1,021 & 4,315 \\
\hline
\end{tabular}

${ }^{1}$ Includes grasslands of savanna, sahelian, and semidesert ecological provinces, and nonarable lands of humid tropics.

${ }^{2}$ Believed to be supported largely on permanent grasslands. Ruminant livestock constitute the principal means of utilizing grazing lands for human support.

${ }^{3}$ South America includes 8 tropical countries; Asia includes 19 tropical and subtropical countries, excluding Mainland China; and Africa includes 33 tropical and subtropical countries.

${ }^{4}$ One cow or buffalo $=5$ sheep $; 1$ goat $=1$ sheep .

the grazing herds. An even greater opportunity is the inclusion of forage plantings in crop rotations on arable lands. It is becoming apparent that sustained land productivity for crops will require such forages in the rotations on arable soils, and the effective use of forages will lift livestock enterprises from the present role of scavengers to a major source of foodstuffs and of cash income. These apparent opportunities have yet to be exploited. However, we do have information on about two dozen superior tropical forage grasses and about a dozen adapted forage legumes. Within a considerable number of these species, there are improved varieties for which seed is available. Australia and Brazil have been leaders in identifying productive forage grasses and legumes and in using these to support livestock enterprises. In many other countries, there has been some field evaluation of promising species so that some basic information is available. The development of practical systems of livestock production based on seeded forages is still in very early stages or is nonexistent.

\section{Savanna and Sahelian Zones}

The savanna and sahelian zones have 20 to 40 inches annual rainfall, and the dry season may extend from 3 to about 8 months. The sahelian zone is the less humid sector of these permanent native grasslands, somewhat comparable to the steppe lands of temperate zones; but low woody species are present in considerable abundance, with intermingled grass and herbaceous growth. Crops are grown extensively in these ecological zones, but are confined largely to soils that are permeable, fairly deep, and comparatively fertile. The lands not arable and native grasslands vary greatly from region to region. In some regions the lands are largely cropped; but in others cropping is restricted to certain favorable soils and all other lands are grazed.

In these regions it is traditional that there are two separate types of agriculture: the roving herdsmen, who own their flocks and herds and use all grazing lands jointly, and the settled farmers living in villages, who are primarily crop producers. While there is some inter-relationship between the two types of culture, the concept of integrated systems of agriculture, employing both crops and livestock enterprises for their mutual support to increase incomes and to reduce the hazards from unpredictable droughts, is hardly ever employed. 
It is in these regions that many abortive efforts have been made by governments, with respect to grazing lands and herdsmen. These efforts have ranged from social and political programs to "settle the nomads," to urban oriented programs designed to force herdsmen to move animals to market for sale at low prices to benefit urban poor people who need meat. In fact, the exploitation of dry rangelands requires the type of roving herdsmen that are now present, and direct assistance for improving range management and livestock production should be fruitful. The integration of livestock and cropping enterprises into combined systems will also require expanding the present cropping systems to include forage production and livestock. Fortunately, we have some of the basic components fairly well identified, such as the improved forage species for both seeded plantings and for range improvement and the basic principles of range management that are largely borrowed from the U.S. range industry.

\section{Semidesert Zone}

The semidesert zone has less than 20 inches natural rainfall; the vegetative cover is sparse but contains appreciable amounts of grass and other palatable forages intermingled with unpalatable short woody plants. The roving herdsmen and their livestock occupying these zones are skilled in survival under existing conditions, and they must be used effectively to improve productivity of these lands.

\section{'While concern is sometimes expressed about the encroachment of useless deserts onto rangelands, this concern has not been translated into effective programs."}

Except perhaps in a few parts of the Middlc East, nothing much has been done to actually apply basic principles of range management and of modern technology to improving semidesert rangelands. While concern is sometimes expressed about the encroachment of useless deserts onto rangelands, this concern has not been translated into effective programs. When serious attention and appropriate resources are directed toward restoration and development of all rangelands, the vast expanses of semidesert ranges in the tropics and subtropics on all continents must receive attention. This is needed to more fully utilize potential resources for national development and to make available to the hardy roving herdsman the improvement in the quality of his living that seems feasible and economically sound.

\section{The Range Code}

It may be useful to examine the factors that seem to control progress in livestock production on rangelands of the tropics and subtropics. The five major categories of limiting factors are:

a) feed supplies and animal nutrition

b) animal disease control and prevention

c) livestock husbandry and management, including water supplies

d) animal breeding (improvement)

e) efficient marketing systems.
The most significant principle that applies to less developed countries is that all of these possible limiting factors must be dealt with simultaneously to make progress. There are many instances where creditable progress has been made with one or more of the categories, but with no visible effect on the end product because some other factor was limiting final productivity. By contrast, in developed regions the more advanced status of range management and the livestock industry makes it possible to deal with one or two limiting factors and to expect prompt benefits when these limitations are reduced. It is proving difficult to convince administrators and other decision makers who become concerned with improving livestock production on rangelands that research must deal simultaneously with multiple limiting factors, and that improved production systems must be similarly balanced to produce significant benefits. As range specialists well realize, livestock production on rangelands is as complex as the entire gamut of crop production; and while research may explore individual facets one by one, the results must be combined into a functional system for the livestock producer. This is true in the tropics, with the additional qualification that the system must be made understandable to the herdsman (or farmer) and be within his capabilities when supported by technical guidance and supporting resources. It is good to remember that the herdsman (Bedouin, nomad, or any other name) is a specialist in survival under the conditions he knows and will accept change only when convinced that the apparent benefits far exceed the hazards and penalties of failure with new ideas.

Perhaps the best way to evaluate the similarities and the differences between the tropics and the temperate zones is to consider each of the 12 principles that constitute the "Range Code."

\section{Adjust Livestock Numbers to Forage Supplies}

This implies use of all available forage to supply feed for the entire year, but it also implies reduction of livestock numbers to stay within predictable feed supplies. With the prevalent custom of nearly complete separation of herdsmen from farmors in tropical regions, complete dependence is placed on rangelands, which seems to be an unnecessary constraint except in drier regions where forage production on arable lands is not feasible. The common practice of using live animals as the resource reserves to tide over disastrous droughts, disease epidemics, or to meet other needs, means that the herdsman is unwilling to cull his herd. He continues to keep nearly all males (uncastrated), as well as other unproductive animals, using up precious feed and water. However, it is becoming apparent that the herdsman will sell stock if he can be assured of a fair price and if he can place such income in a safe and easily accessible repository.

It should be possible to introduce the practice of grazing not more than $60 \%$ of the forage produced each year, thus opening the door for range improvement. When practical methods of providing additional forage from arable lands are developed, he will have an additional margin of flexibility.

\section{Practice Periodic Grazing and Resting of Range Areas}

While this principle appears impossible to implement when

\footnotetext{
${ }^{1}$ The "Range Code" is an arbitrary listing of basic principles of range management and livestock production. It is useful in visualizing range management as an autonomous system.
} 
all rangelands are open to every herdsman, with no regulation, there are hopeful signs. For example, in the Masai tribal regions of East Africa, progress has been made in designating rather large range areas as being predominantly the province of specific tribal groups, even though these groups do not own the land. Also, in Moslem countries there is an Islamic dictum that certain range areas may be designated by the Emir (or comparable ruler) as reserves that are to be grazed only in times of necessity. While the royal decree covering this practice has had various interpretations, this Islamic tradition could be used quite effectively in providing reserve supplies of feed and in achieving range restoration.

\section{"Tropical and subtropical rangeland appear to be degrading at an alarming rate. ..."}

\section{Suppress Undesired Vegetation}

Tropical and subtropical rangelands appear to be degrading at an alarming rate by encroachment of woody and unpalatable plants and by reduction of forage grasses, legumes, and other edible species. Overgrazing, which is a prime causal factor, continues, and comparatively little has been done to control unwanted vegetation by use of herbicides or by mechanical means. Some attempts in brush suppression have not been accompanied by other necessary management practices to achieve range restoration and were not continued. Yearly indiscriminate burning, widely practiced, has done much harm, but is continued because of the more nutritious forage available for a short period when rains occur, coming at the end of a dry season when stock are in a desperate, starved condition.

\section{Introduce and Establish Superior Grasses and Legumes}

Information and materials are accumulating to implement this principle, when companion practices are involved. There are five grasses and two legumes recognized as being adapted to semiarid zoncs, 10 grasses and five legumes for savanna and sahelian zones, and 12 grasses and 10 legumes for wet/dry tropical zones with long dry seasons. The practices likely to be successful for specific soil families, under regulated range use, remain to be worked out in most cases.

\section{Use Controlled Burning as a Management Practice}

It will be difficult to convince herdsmen that burning must be controlled for use as a range improvement practice when they have come to regard it as a rescue operation for starving livestock. Control of burning to have maximum effect on suppression of brush and inedible plants and to provide opportunity for introduction of improved forage species will certainly have to be demonstrated under field conditions and be supported by government actions to become widely adopted. Adoption of other practices-elimination of overgrazing, culling of excess animals, reservation of range areas for feed in critical periods, and other means to prevent chronic starvation-should simplify the problem of getting herdsmen to accept controlled burning.

\section{Improve Soil Storage of Rainfall}

Since moisture supply is a major ecological factor on all subhumid rangelands (in fact, on all grasslands with a dry season of 2 months or longer) prime attention should be given to improving infiltration rates and storage of rainfall in the soil profile. Forage grasses and legumes have a positive effect on soil moisture storage; brush and trees are detrimental. Thus, controlled grazing to improve grass cover and successful rcsceding with adapted forage species should be important practices in range restoration. The fibrous roots of grasses, regenerated yearly, and the deep penetration of legume tap roots tend to progressively improve the soil's capacity to receive and store rainfall, with beneficial effects on feed production.

Water spreading is a practice that may have an important role where the topography is favorable, particularly in the drier regions. It should not be ignored in semidesert regions, even though there may be scant vegetative cover on the smooth areas to which water is led. Bulrush millet (pearl millet) is an excellent tropical forage species to plant on new areas where water spreading is to be practiced, until such time as perennial species can be established.

\section{Provide Stock Water to Serve Forage Growing Areas}

The availability of stock water supplies within a few hours' walk is important in drier regions. As the dry season progresses, herdsmen take their flocks to scanty feed sources that are more and more distant from water. Stock that are grazed more than one day's walk for the livestock are under severe stress, and the animals become quite desperate when watered only once in two or three days. Survival, rather than production, becomes the dominant consideration. The stress of aggravated thirst is most serious for the breeding herd and younger animals, and this affects the reproduction and growth rates.

Herdsmen badly need the assistance of governments in developing water resources through construction of ponds to impound runoff, wells to exploit subsurface aquifers, or cisterns in the dry washes of semiarid regions. Very little attention has been given by governments to the discovery and development of stock water supplies to permit exploitation of forage in dry seasons. AID has made some successful efforts in this direction, but this assistance will be most effective as a component of a complete range management system.

\section{Protect Breeding Herds from Under-nutrition and \\ Malnutrition}

Despite the general knowledge that forage becomes steadily less nutritious as the dry season continues, little has been done to cope with this problem. Herdsmen (and others) do not realize that the energy in low-protein, fibrous forage, is incompletely used when protein falls to such low levels as $6 \%$. Maintenance of body weight declines, and growth and reproduction come to a halt. This is one factor that would be promptly alleviated if harvested forage on arable land could be utilized to improve protein and mineral intake of animals otherwise subsisting on low-grade roughage. For example, the possibility of using oil seed cake (often wasted or sold for low prices) as a high protein supplement will become more feasible when integrated crops/livestock systems are practiced, and livestock become an important cash "crop."

Under-nutrition can be alleviated by controlled stocking 
rates, use of rangelands held in reserve for dry seasons, and by use of forage from arable lands. To the extent that legumes are present in such forages, they should combat protein malnutrition. These opportunities are rarely being exploited in the tropics and subtropics. We believe the situation will soon change in Latin America, where the collection, collation, and interpretation of all available feed composition data by the University of Florida under an AID contract now provides exceedingly useful data on the nutritive value of native feeds. Livestock specialists in many Latin American nations are enthusiastically participating in this program, and this movement should have a profound effect on livestock production on grasslands. This activity should be extended to Africa and Asia.

\section{Practice Systematic Animal Health Control Measures}

The catastrophic effect of uncontrolled disease is known to most herdsmen. They also are aware that diseases such as rinderpest can be controlled by vaccination, and there is little or no resistance to the whole range of health control measures that may be undertaken. These herdsmen are completely dependent on external assistance for effective animal health control measures. Controlling ticks by regular schedules of dipping has been promptly adopted by the Masai tribes in Tanzania and Kenya as soon as the facilities and technicians were available. It should be recognized that diseases of all types and ecto- and endoparasites may flourish throughout the year in the tropics and subtropics, so that animal health programs have greater urgency in these warm regions than in the temperate zones.

Probably the greatest weakness on the part of governments has been lack of understanding that control of a serious disease, such as rinderpest, produces little effect on overall livestock production unless all other major constraints are dealt with simultaneously. This is the reason for discouragement with disease control programs, resulting in reduction of budgets and disillusionment as to the future of the livestock industry.

\section{Reconcile Competitive Demands for Milk to Meet Home Needs and to Raise Calves}

This is a serious problem in most herdsmen's flocks and herds because of the crucial role of milk in meeting family needs. This problem is not so acute for crop farmers who also have some livestock, but the herdsman who derives the majority of his foodstuffs from his animals as milk and meat (and blood in many African regions) has daily needs for milk. The calves (lambs or kids) are dependent on the same supply of milk for survival and growth. Since indigenous animals, under range conditions, produce low volumes of milk and lactation periods are short, there is insufficient milk for the calf and for family use. Usually, the calf is progressively deprived as the dry season progresses and the supply and quality of feed decreases. The end result is a stunted calf or failure to survive. The maintenance of a herd of strong animals is nearly impossible when regeneration is largely dependent on stunted calves.

This problem could be reduced if cows were bred to freshen at the flush period of forage growth, following onset of rains, so that milk flow would be continued for a longer period and both calf and family would be more nearly satisfied. Even that system fails to provide continuing milk flow in dry seasons. Milk flow on a year-round basis is feasible only if adequate feed and water are available throughout the year.

\section{Undertake a Sound Program for Livestock Improvement}

There has been a strong belief by livestock specialists in the western world that indigenous livestock of the tropics are lacking in hereditary traits needed for a strong livestock industry. This has led to efforts to make giant strides in herd improvement by importing exotic types and breeds of livestock from temperate zones. This has not led to the anticipated benefits, since the exotic stock are usually poorly adapted to hot climates, lack resistance to endemic diseases and parasites, and are poorly suited to the acquisition and conversion of local forages for nutritional needs. Serious efforts should be made to selectively increasing the productivity of indigenous types and breeds, rather than attempting to by-pass the basic genetic factors of production by importing exotic germ plasm or semen from such animals in the hope of instant improvement. Imports of tropical breeds from other similar regions may have practical value for herd improvement to be practiced by herdsmen. It is well known that the development of new breeds from crosses of widely different types requires large animal populations and sustained control of selection over six to ten animal generations. This type of animal breeding by hybridization with exotic breeds requires stable and sustained allocation of resources and the direction of competent animal geneticists supported by other specialists in animal nutrition, animal health, and animal husbandry.

There is a very real need for the improvement of indigenous breeds that is well within the resources of every developing country. Most herdsmen are aware of the superior attributes of some members of the herd or flock (a traditional awareness going back at least to the times of Jacob), but little use has been made of this knowledge for herd improvement. However, the possibility of significant selection and propagation of desirable traits should be greatly improved as supplies of feed and water become more stable and enlightened management of the herd results in stronger and earlier maturing breeding stock. Reduced mortality and larger calf crops also will give the breeder a greater opportunity to select animals that appear to have superior inheritance, as distinguished by escape and survival from all of the prevalent hazards that otherwise afflict livestock production.

In a herd of cattle with stabilized production, one healthy bull should be capable of serving 20 to 25 cows. All other males should be removed from the breeding herd. Selection of bulls with desirable conformation, which are the offspring of productive cows, is a particularly effective method of herd improvement, since each such bull imparts his inheritance to all the calves he sires. When the choice of bulls is accompanied by selection of the better cows for his service, genuine improvement in each successive animal generation becomes possible. This method is applicable also to buffaloes, sheep, and goats.

\section{Establish a Program for Timely and Orderly Marketing of Livestock}

This is actually a complex of many factors, including transportation of livestock to markets, setting up classes and standards for establishing market values, equitable pricing to the herdsmen, slaughter and processing, and efficient movement of meat to the ultimate consumer. There are other factors also, such as safe repositories made available to the herdsmen when he sells his animals, that is, even more 


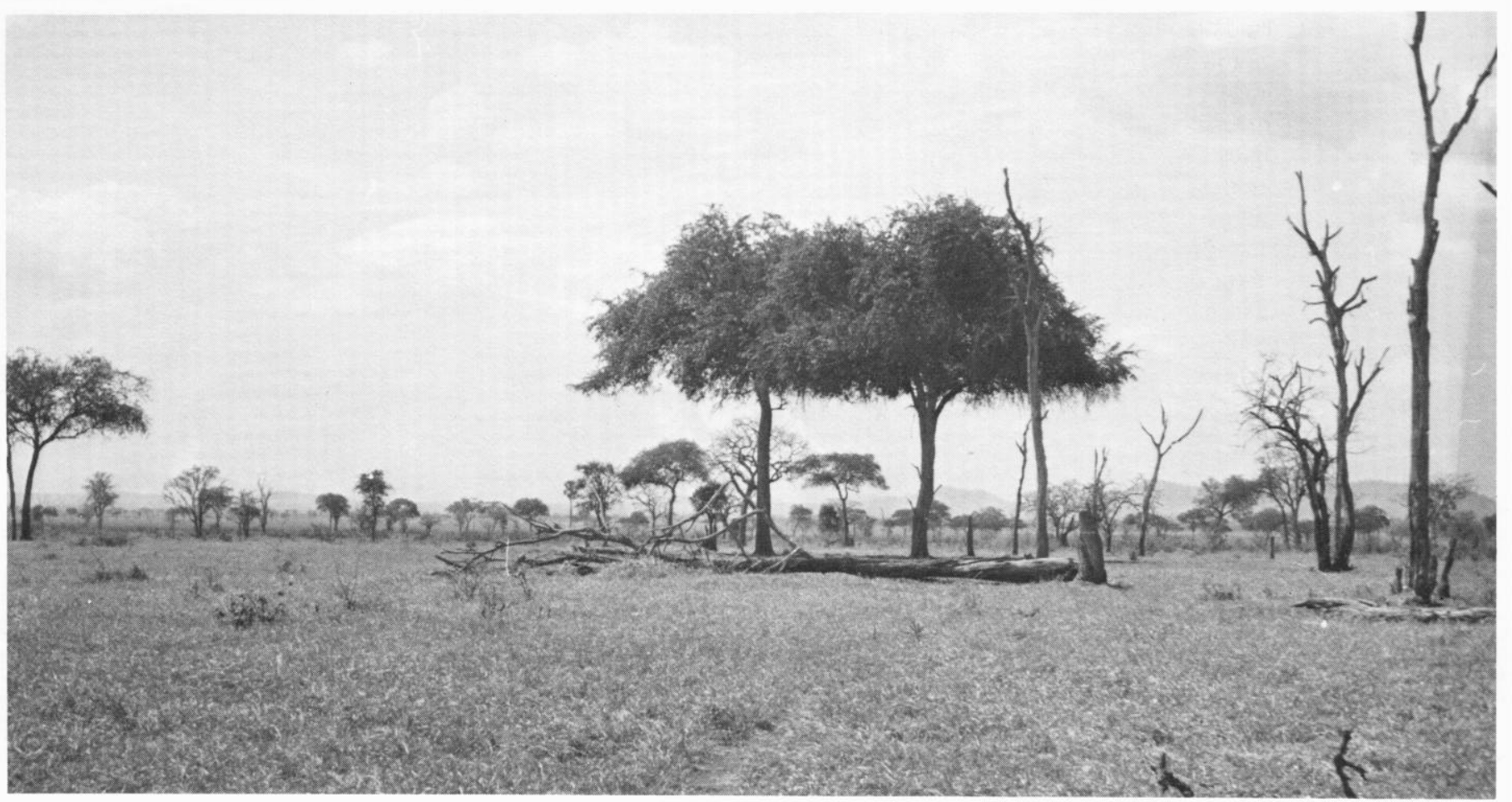

acceptable to him than holding his animals alive in his own herd to meet his subsistence needs. He is not likely to market all excess males (sometimes 50\% of his herd), as well as barren females, when they serve as capital reserves with which he is able to survive in terms of adversity.

Extensive studies have been made by AID, FAO, and other agencies on livestock marketing without sufficiently relating the marketing function to the production aspect of the industry and the needs of the herdsman, who is intent on survival and protection of his family. Marketing is a prime factor, but it does not stand alone. Marketing must be considered as part of the system of livestock production. It will not do to attempt to influence marketing solely for the benefit of the urban population that needs meat. The livestock belong to the herdsman and are managed by him. Improved production programs must be aware of the role of natural resources in country development and the herdsmen's use of these, accompanied by an efficient marketing system.

\section{Group Action to Make Range Improvement Possible}

This is a unique problem of most developing countries, where grazing lands are not owned by the herdsmen and are not fenced. The animals used to graze these lands are owned by individuals or family groups, but are grazed in communal flocks and herds on open grazing lands. In general, there is no limit to the number of animals that each owner contributes to the communal grazing group. Also, there is no effective restriction on the use of rangelands and other permanent grasslands by herds and flocks of other communal groups, except those of ill-defined tradition.

Under these conditions, there is no inducement for undertaking such practices as control of stocking rates, rotation or deferred grazing, the establishment of feed reserves, suppression of brush, or other range improvement practices. Neither is it feasible to undertake development of stock water supplies, herd improvement, or other practices that involve management of total populations of livestock.

To make possible effective programs for improving livestock production on rangelands, it is necessary to have acceptable allocations of range areas to specific groups of livestock producers, even though such allocations do not convey actual title to the land. When exclusive allocations of rangelands are made to the pastoral groups traditionally associated with these lands, or to other groupings that are identified, there is then an inducement to the users to undertake sustained range protection and improvement and the associated livestock management practices. The designated group can then take collective action to improve production with the expectation of reaping the rewards or of paying the penalty in reduced productivity for not undertaking appropriate action.

The mechanism of forming self-governing "associations" made up of livestock producers in a specified region and of making governmental technical assistance available to such associations is a promising approach. Such group actions should improve the potential for more efficient production and marketing without disturbing private ownership of livestock. 